\title{
Do different arbuscular mycorrhizal fungi affect the formation and stability of soil aggregates?
}

\section{Diferentes fungos micorrízicos arbusculares afetam a formação e estabilidade de agregados do solo?}

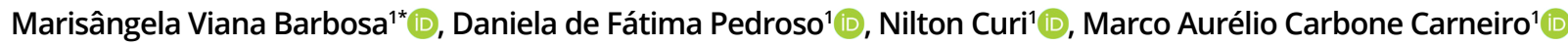

'Universidade Federal de Lavras/UFLA, Departamento de Ciência do Solo/DCS, Lavras, MG, Brasil

*Corresponding author: mvbarbosa10@gmail.com

Received in February 10, 2019 and approved in May 9, 2019

\begin{abstract}
Soil structure, which is defined by the arrangement of the particles and the porous space forming aggregates, is one of the most important properties of the soil. Among the biological factors that influence the formation and stabilization of soil aggregates, arbuscular mycorrhizal fungi (AMF) are distinguished due to extrarradicular hyphae and glomalin production. In this context, the objective of this study was to evaluate different AMF (Acaulospora colombiana, Acaulospora longula, Acaulospora morrowiae, Paraglomus occultum and Gigaspora margarita) associated with Urochloa brizantha (A. Rich.) Stapf on soil aggregate stability. The study was conducted in a completely randomized design, using an Oxisol and autoclaved sand 2:1 (v/v), with seven treatments: five AMF; and treatments with plants without inoculation and with only the soil, with 5 replicates. The experiment was conducted during 180 days and the following variables were evaluated: mycelium total length (TML); production of easily extractable glomalin-related soil protein (GRSP) in the soil and aggregate classes; stability of the dry and immersed in water aggregates through the mean geometric diameter (MGD) and the mean weighted diameter (MWD) of aggregates; and the soil aggregate stability index (ASI). It was observed that the inoculation favored soil aggregation, with a high incidence of $A$. colombiana, which presented the highest MGD, TML and GRSP production in the aggregates with $\varnothing>2.0 \mathrm{~mm}$ and for $A$. colombiana and $A$. morrowiae in the aggregates with $\emptyset<0.105 \mathrm{~mm}$, when compared to the treatment without inoculation. These results show that there is a distinction between the effects of different AMF on the formation and stability of soil aggregates.
\end{abstract}

Index terms: AMF; Urochloa brizantha; extrarradicular mycelia; aggregation soil and structure.

\section{RESUMO}

A estrutura é uma das propriedades mais importantes do solo, definida pelo arranjo das partículas e do espaço poroso formando agregados. Dentre os fatores biológicos que influenciam a formação e estabilização dos agregados no solo, destacam-se os fungos micorrízicos arbusculares (FMAs) através das hifas extrarradiculares e produção de glomalina. Nesse contexto, o objetivo desse estudo foi avaliar diferentes FMAs (Acaulospora colombiana, Acaulospora longula, Acaulospora morrowiae, Paraglomus occultum e Gigaspora margarita) associadas com Urochloa brizantha (A. Rich.) Stapf na estabilidade de agregados do solo. O estudo foi conduzido em delineamento inteiramente casualizado, utilizando Oxisol e areia lavada 2:1 (v/v) autoclavada, com sete tratamentos: cinco FMAs; tratamentos com plantas sem inoculação e com apenas o solo, com 5 repetições. $O$ experimento foi conduzido durante 180 dias, avaliando: comprimento do micélio total (CMT); produção de proteína do solo relacionada à glomalina facilmente extraível (PSRG) no solo e nas classes de agregados; estabilidade dos agregados a seco e imersos em água, através do diâmetro médio geométrico (DMG) e diâmetro médio ponderado (DMP) dos agregados; e o índice de estabilidade de agregados (IEA). Observou-se que a inoculação favoreceu a agregação do solo com destaque para A. colombiana, que apresentou o maior DMG, CMT e produção de PSRG no agregados $\varnothing>2,0 \mathrm{~mm}$ e para. $A$. colombiana e $A$. morrowiae nos agregados com $\emptyset<0,105 \mathrm{~mm}$, quando comparadas ao tratamento sem inoculação. Esses resultados mostram que há distinção dos efeitos dos diferentes FMAs no processo de formação e estabilidade dos agregados do solo.

Termos para indexação: FMAs; Urochloa brizantha; micélio extrarradicular; agregação do solo e estrutura.

\section{INTRODUCTION}

Soil structure is considered one of the most important properties of soils because it exerts an essential action in soil quality maintenance, guaranteeing its greater resilience considering biotic and abiotic stresses (Rabot et al., 2018). The structure is formed by different and complementary processes that result from the interactions of the chemical, physical and biological factors of the soil (Tisdall; Oades, 1982; Lehmann; Leifheit; Rillig, 2017), 
as well as the soil spatial distribution, which is inherent to geological and pedological factors of soil formation and mineralogy (Ferreira; Fernandes; Curi, 1999 a, b; Ye et al., 2018). Well-structured soils present stable aggregates that favor the growth of the roots, increase the biological activity and the diverse ecological relations in the soil.

The biological activity excerts essential function in the process of aggregate formation and soil structural stability. Among the groups of microorganisms that play important functions in the construction of the soil structure are the arbuscular mycorrhizal fungi (AMF), which act in the formation and stabilization of the aggregates, besides contributing in terms of nutritional benefits, support to diverse stresses and promotion of growth to the plants in different phytophysiognomies (Rubin; Stürmer, 2015; Lehmann; Zheng; Rillig, 2017; Singh; Ghosh, 2018; Marinho et al., 2019).

The influence of AMF on aggregation is mainly attributed to extraradicular hyphae and to soil protein production related to glomalin (Rillig; Muller; Anika, 2017; Lehmann; Leifheit; Rillig, 2017). The hyphae act in the orientation of soil particles during growth on extrarradicular fungal mycelium by the "mechanical" action of pressure of the particles, forming microaggregates adjacent to the mycelia and later by the release of glomalin, which exerts an aggregating and cementing effect in the soil (Vilela et al., 2014; Rubin; Sturmer; 2015; Lehmann; Leifheit; Rillig, 2017; Kinany et al., 2018).

In soils from tropical regions, this influence of AMF on aggregate formation becomes particularly important, especially in Oxisols of the Cerrado Biome (Ferreira; Fernandes; Curi, 1999a, b). The mineralogical composition of the clay fraction is dominated by kaolinite, which presents low cation exchange capacity (CEC), fallowed by iron and aluminum oxides, and the Oxisols heve high organic matter decomposition rate (Ferreira; Fernandes; Curi, 1999 a, b). Considering that the predominance of the genesis of the smaller-sized aggregates is attributed to the mineralogical composition of the soil (Lima; Anderson, 1997), the importance of other factors for macroaggregate formation, especially the biological factor should be considered.

However, although the general influence of AMF on soil aggregation (Rubin; Stürmer, 2015; Lehmann; Leifheit; Rillig, 2017) is known, only few studies demonstrate the contribution of different AMF species in this regard. Thus, the hypothesis of this study is related to the differences in the effects of AMF on the formation and stability of soil aggregates.
Therefore, the objective this study was to evaluate the effects of different species of arbuscular mycorrhizal fungi - AMF (Acaulospora colombiana, Acaulospora longula, Acaulospora morrowiae, Paraglomus occultum and Gigaspora margarita) associated with Urochloa brizantha (A. Rich.) Stapf on the stability of soil aggregates, using an Oxisol.

\section{MATERIAL AND METHODS}

The study was conducted under glasshouse conditions at the Federal University of Lavras during a period of 180 days, using a mixture of washed medium sand and Oxisol (Soil Survey Staff, 2014) at a ratio of 2:1 (v/v), respectively. The chemical and physical characterizations of the substrate were: $\mathrm{pH}$ (water) $=5.4 ; \mathrm{H}+\mathrm{Al}=2.9 \mathrm{cmol}_{\mathrm{c}}$ $\mathrm{dm}^{-3} ; \mathrm{Ca}=1.70 \mathrm{cmol}_{\mathrm{c}} \mathrm{dm}^{-3} ; \mathrm{Mg}=0.10 \mathrm{cmol}_{\mathrm{c}} \mathrm{dm}^{-3} ; \mathrm{K}=18$ $\mathrm{mg} \mathrm{dm}-3 ; \mathrm{P}=1.13 \mathrm{mg} \mathrm{dm}^{-3} ; \mathrm{SOM}=2.11 \mathrm{dag} \mathrm{kg}^{-1}, 41 \mathrm{dag}$ $\mathrm{kg}^{-1}$ of clay, $53 \mathrm{dag} \mathrm{kg}^{-1}$ of sand and 6 dag kg-1 of silt. The mineralogy of this soil (predominance of quartz in the sand and silt fractions, and of kaolinite, gibbsite, goethite and hematite in the clay fraction) favors the development of the granular structure that is typical of Oxisols of tropical regions (Ferreira; Fernandes; Curi, 1999 a, b). The mixing was autoclaved at $121^{\circ} \mathrm{C}$ during $1 \mathrm{~h}$ for two consecutive days, and then stored in pots with a capacity of $1 \mathrm{~kg}$ for the elimination of native arbuscular mycorrhizal fungi (AMF) propagules. The planting and execution of the study started 30 days after that.

Seven treatments were used for the execution of this study: five different AMF (Table 1), one treatment with plants without inoculation and one treatment including only soil (without plants and without inoculation), in a completely randomized design (CRD), with five replications. The treatment without plants was used to evaluate the effect of root presence (associated or not to inoculation) on soil aggregation. The AMF used in this study are of generalized occurrence and were isolated from areas under Cerrado (Neotropical Savana). They were multiplied at the glasshouse using Urochloa brizantha (A. Rich.) Stapf (Table 1).

The experiment was conducted using seeds of Urochloa brizantha (A. Rich.) Stapf, which were disinfested in a solution of sodium hypochlorite at $0.5 \%(\mathrm{v} / \mathrm{v})$ during five minutes and washed with sterile distilled water. Each pot contained 20 seeds, and 15 days after germination the plants were thinned out, remaining ten plants per pot. The inoculation was performed using soil-inoculum containing nearly 150 spores of each inoculated AMF, which in addition to the spores, contained hyphae and colonized roots that also act as infective propagules of AMF. 
Table 1: The AMF used in the study, identified by means of the deposit code in the AMF culture collection of the Federal University of Lavras (UFLA).

\begin{tabular}{ccc}
\hline AMF & & Codes \\
\hline Acaulospora colombiana & (Spain \& Schenck) Kaonongbua, Morton \& Bever & 537 UFLA \\
Acaulospora longula & Spain \& Schenck & 242 UFLA \\
Acaulospora morrowiae & Spain \& Schenck & 467 UFLA \\
Gigaspora margarita & Becker \& Hall & 252 UFLA \\
Paraglomus occultum & (Walker) Morton \& Redecker & 438 UFLA \\
\hline
\end{tabular}

During the conduction of the experiment, $20 \mathrm{~mL}$ of nutrient solution composed of $210 \mathrm{mg} \mathrm{L}^{-1} \mathrm{~N}, 234 \mathrm{mg}$ $\mathrm{L}^{-1} \mathrm{~K}$, and $15.05 \mathrm{mg} \mathrm{L}^{-1} \mathrm{P}$, corresponding to $50 \%$ of the recommended $\mathrm{P}$ concentration, were used. The study was conducted during 180 days and the pots were maintained with moisture equivalent to $60 \%$ of pore total volume (PTV).

At the end of the experiment, the following variables were determined: length of roots (LR), dry mass of roots (DMR), number of spores (NS), mycorrhizal colonization (MC), length of total extraradicular mycelium (TML), production of soil protein related to easily extractable glomalin (GRSP) in the soil and in the classes (interior) of the aggregates, stability of aggregates (dry and wet), through the geometric mean diameter (MGD), mean weighted diameter (MWD), and soil aggregate stability index (ASI).

The number of spores was quantified using $50 \mathrm{~mL}$ of soil of each treatment by the wet sieving technique (Gerdemann; Nicolson, 1963) and centrifugation in water and sucrose solution (Jenkins, 1964). Spore counting was carried out directly on corrugated plates under a stereoscopic microscope. Mycorrhizal colonization was quantified by the technique of intersection in reticulated plates (Giovannetti; Mosse, 1980), using $1 \mathrm{~g}$ of fine roots, according to Phillips and Hayman (1970).

The length of soil extrarradicular mycelium was determined according to Melloni and Cardoso (1999), using the following equation:

$C=\frac{[(0.21387 \times N)]}{(10-\mathrm{U})}$

Where:

$\mathrm{C}=$ Extrarradicular mycelium length for each $\mathrm{m} \mathrm{g}^{-1}$ of dry soil;

$\mathrm{N}=$ Number of intersections of hyphae with the horizontal

lines grid; and

$\mathrm{U}=$ Amount of water present in $10 \mathrm{~g}$ of wet soil, in grams.
The concentration of GRSP was evaluated by the method of Wright and Upadhyaya (1998), and quantified using a spectrophotometer, according to the method of Bradford (1976). The concentration of GRSP ( $\mathrm{mg} \mathrm{g}^{-1}$ soil) were estimated using the standard curve equation $(\mathrm{y}=0.0082 \mathrm{x}$ $\left.+0.481 ; \mathrm{R}^{2}=0.99^{* *}\right)$, which was obtained by serum Bovine Albumin (SBA) as the purified standard protein.

Soil aggregate stability was determined according to Kemper and Chepil (1965), using the mean geometric diameter (MGD) and weighted mean diameter (MWD) parameters. For this, the soil aggregates distribution was determined by sieving dry aggregates and pre-wetted aggregates.

Soil aggregates were determined using the Yoder (1936), being classified as macroaggregates $(\varnothing \geq 2.0 \mathrm{~mm})$, mesoaggregates $(2.0>\varnothing \geq 0.25 \mathrm{~mm})$ and microaggregates $(\varnothing<0.105 \mathrm{~mm})$ and from which the MGD, MWD and ASI were determined. The concentration of GRSP within the aggregates after fractionation was also determined.

MGD and MWD were obtained in ( $\mathrm{mm}$ ) using the following equations (Kemper; Chepil, 1965):

$$
\operatorname{MWD}=\sum_{i=1}^{n}\left(x_{i \cdot w i}\right) \quad \mathrm{MGD}=\exp \left[\frac{\sum_{i=1}^{n} w_{i} \log x_{i}}{\sum_{i=1}^{n} w_{i}}\right]
$$

Where: $\mathrm{X}_{\mathrm{i}}=$ average diameter of classes $(\mathrm{mm})$; and $\mathrm{W}_{\mathrm{i}}=$ proportion of each class in relation to total weight (\%):

For the stability index of aggregates, the following equation was used according to Silvia and Mielniczuk (1997):

$\mathrm{ASI}=\frac{\mathrm{MWDW}}{\mathrm{MWDd}}$

Where: ASI = Aggregate Stability Index;

MWDw $=$ Weighted mean diameter, obtained by wet sieving $(\mathrm{mm})$; and

MWDd $=$ Weighted average diameter, obtained by dry sieving $(\mathrm{mm})$. 
The data were tested for normality and transformed to $\log (\mathrm{x}+1)$ for mycorrhizal colonization and number of spores. Analysis of variance (ANOVA) was performed and the averages were compared using the Tukey test at 5\% probability, via SISVAR software (Ferreira, 2011). A correlation was also performed to evaluate the influence of AMF on the parameters of soil agreggation.

\section{RESULTS AND DISCUSSION}

The formation of soil aggregates was differently influenced by AMF, as verified by means of dry and wet geometric mean diameters (MGDd and MGDw) (Figure 1). The inoculation with 537 UFLA showed the best results for MGDd, MGDw, total extrarradicular mycelium length (TML) and higher concentration of glomalin-related soil protein (GRSP) within the aggregates with diameter $\varnothing>2.0 \mathrm{~mm}$ (Figures 1A, 1B, 1C, and Figure 2). The inoculation with 537 UFLA did not differ significantly $(\mathrm{p}<0.05)$ from 242 UFLA, 467 UFLA, 438 UFLA and 252 UFLA. However, it was found to provide greater increase in the formation of MGDd when compared with non-inoculated soil and absence of plants (Figure 1A).

On the other hand, 537 UFLA and 242 UFLA had the greatest effects on the formation of MGD, with 537 UFLA differing significantly $(\mathrm{p}<0.05)$ from other treatments (Figure 1B). For TML, the inoculation with 537 UFLA, 242 UFLA, 467 UFLA and 438 UFLA showed no difference $(\mathrm{p}<0.05)$ in mycelial length. However, 537 UFLA showed a higher TML with an increase of up to 32 fold when compared with the treatment without inoculation
(Figure 1C). Never the less, inoculation with 252 UFLA showed smaller increment with 4.4 fold in TML.

Soil aggregation occurs through a sequence of chemical, physical and biological processes (Tisdall; Oades, 1982; Ferreira; Fernandes, Curi, 1999 a, b; Lehmann; Leifheit; Rillig, 2017). Biological action is mainly based on the processes of bioturbation and composition. The first by the movement of soil particles and the second by the release of exudates, secretions, and proteins among other more complex substances, which help as cementing agents of aggregates.

The present study showed the positive effects of FMA inoculation on soil aggregates, mainly by exerting biophysical and biochemical actions, which included the formation of extra-tricus hyphae and the production of glomalin (Rillig; Mummey, 2006; Lehmann; Leifheit; Rillig, 2017). The hyphae exert an important action in the aggregation of the soil acting in the folding (mechanical action), orientation and reorganization of the particles, making them more stable. Further more, glomalin acts as cementing agent of the mineral and organic particles of the soil (Rillig et al., 2010; Lehmann; Zheng; Rillig, 2017; Ji; Tana; Chen, 2018). In addition, AMF favor the microbiota that inhabits the mycorrhizasphere, which acts on decomposition and mineralization, producing the organic matter that also acts as a cementing agent. These mechanisms favor the dynamics of soil organic carbon, improving the stability of aggregates. Such processes also act to increase the $\mathrm{C}$ stock in the soil, which is an important factor in reducing the release of gases and increasing the greenhouse effect in the atmosphere.
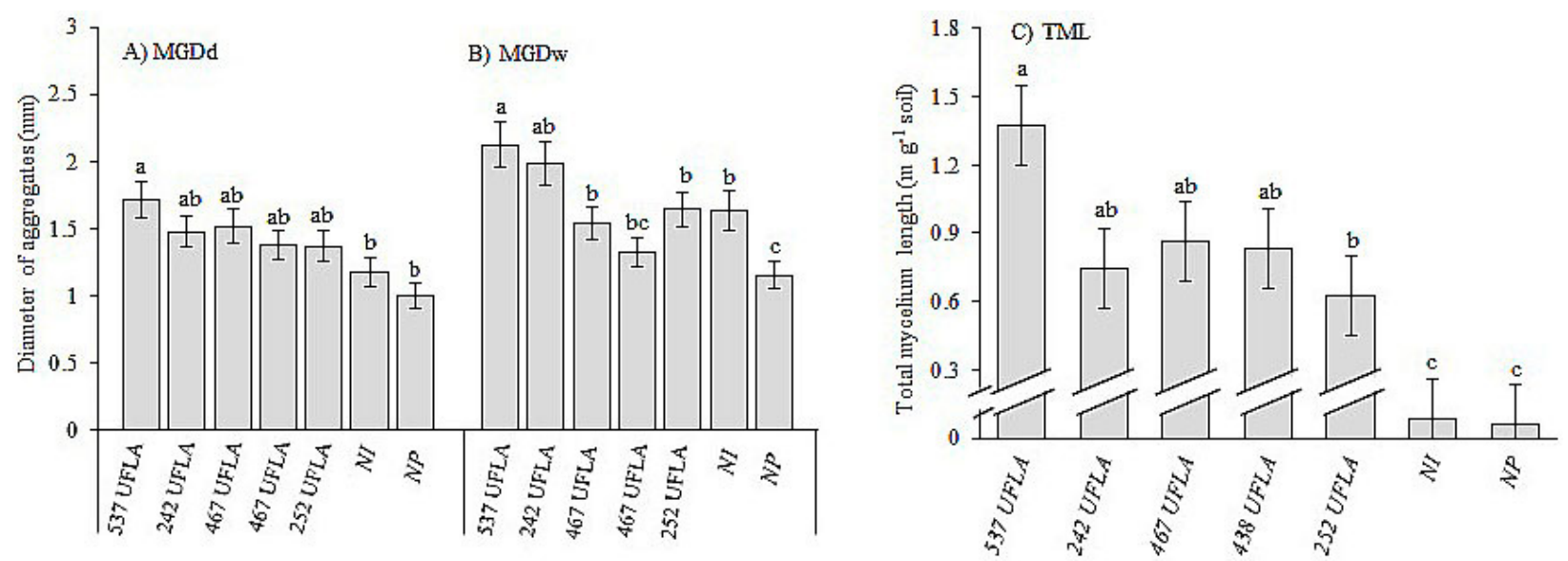

Figure 1: Mean geometric diameter when dry (MGDd); when wet (MGDw) and total extrarradicular mycelium length (TML) of soil/substrate cultivated with U. brizantha, being: $A$. colombiana (537 UFLA); A. longula (242 UFLA); A. morrowiae (467 UFLA); P. occultum (438 UFLA); G. margarita (252 UFLA); uninoculated (NI); and absence of plant (NP). Equal letters do not differ significantly by the Tukey test at $5 \%$. 
Studies have shown that the $\mathrm{C}$ accumulation in the soil is based on stabilization mechanisms, considering the interactions between the organic material and the surface of the mineral particles, and that the formation of aggregates exerts a protective effect on $\mathrm{C}$ against decomposing microorganisms of soil (Lehmann; Leifheit; Rillig, 2017; Rillig; Muller; Anika, 2017), reducing mineralization. The accumulation of $\mathrm{C}$ is greater in the soil macroaggregates, because this same $\mathrm{C}$ assists in the cementation of this type of aggregates, which are generally more correlated with the length of the mycelium than with the production of glomalin (Rubin; Stürmer, 2015; Lehmann; Leifheit; Rillig, 2017; Rillig; Muller; Anika, 2017; Kinany et al., 2018). Our data corroborate with this assertion, where mycelial production was positively correlated with the aggregates with $\varnothing>2.0 \mathrm{~mm}$. In field observations, Kohler et al. (2017) also verified the effect of extraradicular hyphae on the stability of aggregates, regardless of soil texture.

The concentration of glomalin was higher in macroaggregates inoculated with 537 UFLA (Figure 2). In the microaggregates inoculated with 537 UFLA and 438 UFLA, AMF had the highest contribution in the production of glycoprotein (Figure 2). However, the concentration of GRSP evaluated in the soil samples showed no significant difference $(\mathrm{p}<0.05)$ between the inoculated AMF. When compared to non-inoculated plants and non-inoculated treatments, there was an increase in glomalin production (Figure 3A), which highlights the importance of AMF in the production of this recalcitrant $\mathrm{C}$ source glycoprotein in the soil. However, for ASI, there was no significant difference $(p<0.05)$ in the inoculation of AMF with the non-inoculated treatments and with the non-inoculated plants, being different $(p<0.05)$ only from the control without plants (Figure 3B). This result demonstrates that ASI is strongly related to root presence in the soil, mainly considering it is a case a grass with an abundant root system that assists in the formation of soil aggregates stability.

The highest increases in the production of glomalin in the soil were verified for inoculation with 467 UFLA, which presented an increase of $2.180 \mathrm{~kg}$ of GRSP ha ${ }^{-1}$, followed by 438 UFLA with $1.500 \mathrm{~kg}$ of GRSP ha- ${ }^{-1}, 537$ UFLA with $1.340 \mathrm{~kg}$ of GRSP ha ${ }^{-1}, 242$ UFLA with $1240 \mathrm{~kg}$ of GRSP $\mathrm{ha}^{-1}$ and 252 UFLA with $1020 \mathrm{~kg}$ of GRSP ha- ${ }^{-1}$. Considering that glomalin has a high amount of $\mathrm{C}$ in its composition, inoculation with these AMF species represents an important increase in soil organic C (Peng; Guo; Liu, 2013; Rillig; Muller; Anika, 2017), which indirectly contributes to the formation and stability of the aggregates.

When comparing the concentration of glomalin between the inoculated and non-inoculated treatments with the presence of plants, there was an increase of $1.09 \mathrm{mg}$ $\mathrm{g}^{-1}$ of soil for 467 UFLA and $0.51 \mathrm{mg} \mathrm{g}^{-1}$ of soil for 252 UFLA (Figure 3A). The concentration of glomalin found in treatments without AMF and without plants refers to the residual effect of glomalin in the soil, produced by native AMF species of this soil and remaining stable, demonstrating the effect of this glycoprotein on storing carbon in the soil.

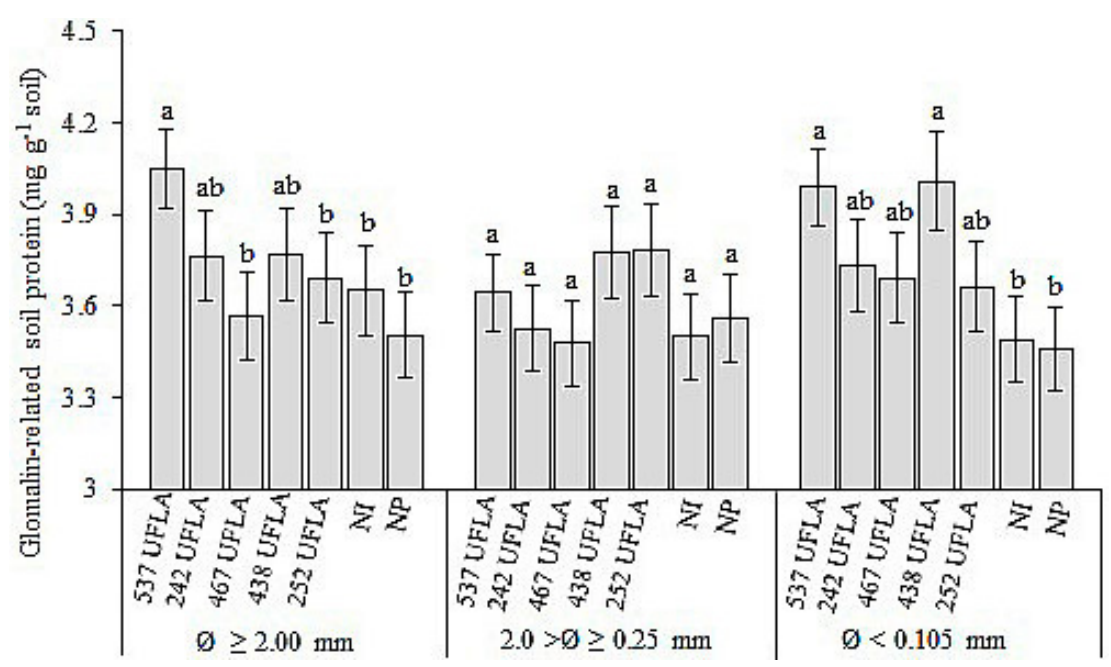

Figure 2: Concentration of soil protein related to easily extractable glomalin (GRSP), in the aggregate classes: macroaggregates $(\varnothing>2.0 \mathrm{~mm})$, mesoaggregates $(2.0>\varnothing \geq 0.25 \mathrm{~mm})$ and microaggregates $(\varnothing<0.105 \mathrm{~mm})$. Being: $A$. colombiana (537 UFLA); A. longula (242 UFLA); A. morrowiae (467 UFLA); P. occultum (438 UFLA); G. margarita (252 UFLA); uninoculated (NI); and absence of plant (NP). Equal letters do not differ significantly by the Tukey test at $5 \%$. 

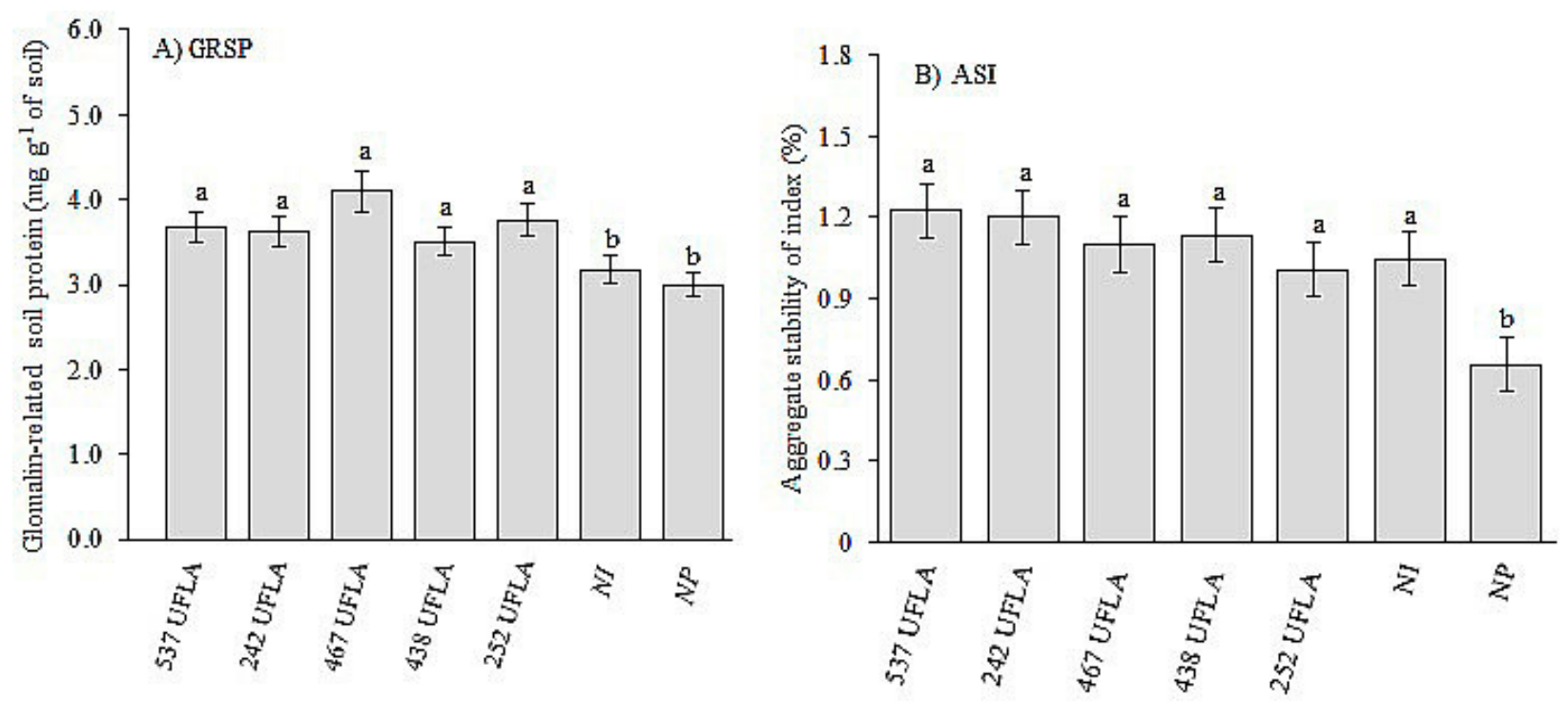

Figure 3: Concentration of soil protein related to easily extractable glomalin (GRSP) and aggregate stability index (ASI) in plants inoculated with different species of AMF. Being: A. colombiana (537 UFLA); . longula (242 UFLA); . morrowiae (467 UFLA); P. occultum (438 UFLA); G. margarita (252 UFLA); uninoculated (NI); and absence of plant (NP). Equal letters do not differ significantly by the Tukey test at $5 \%$.

When evaluating root length and dry mass, there was no significant difference $(\mathrm{p}<0.05)$ between the treatments (Table 2), indicating that for the conditions of this study, roots were not the main factors that explain the differences between MGDw and MGDd, and that the observed effects are probably associated with the production of hyphae from AMF (Figures 1A, 1B, and 1C). Corroborating with this study, Ji, Tana and Chen (2018) also observed a greater effect of the extrarradicular hyphae of AMF on soil aggregation.

The number of spores recovered from the soil varied as function of the inoculated AMF, with 537 UFLA being the species with the highest sporulation and 252 UFLA being the one with the lowest spore multiplication (Table 2). These results also influenced the concentrations of glomalin in the soil, considering that during the degradation of the AMF spores, there is an increase in the concentration of glomalin in the soil (Steinberg; Rillig, 2003; Driver; Holden; Rillig, 2005). In the present study, a relationship between the number of spores and the presence of glomalin in the soil was observed. This effect was verified for 537 UFLA, which presented 41 spores and high TML, and there was no significant difference $(\mathrm{p}<0.05)$ for GRSP among the inoculated AMF (Figure 3A). As for 242 UFLA and 438 UFLA, there was an inverse effect, in which these AMF presented low TML and high NS, 423 and 138 spores (50 $\mathrm{ml}$ of soil), respectively. For 467 UFLA, it was verified NS of 36 spores and low TML, whose production of GRSP is associated with intrinsic characteristics of this species, which usually presents great potential of production of this glycoprotein (Wright; Nichols, 2002). For 252 UFLA, which presented low TML and NS (11 spores), there was also no significant $(\mathrm{p}<0.05)$ diference compared to the other AMF inoculated for GRSP. These results suggest a proportional relationship considering that 252 UFLA has larger spores than the other studied AMF (Figure 3A and Table 2). Steinberg and Rillig (2003) observed that there was an increase in the amount of glomalin after 150 days in soil incubated with absence of plants, suggesting that the increase of glomalin concentrations occurred due to the degradation of fungal hyphae and spores of AMF, corroborating with the present study.

The way the different AMF act on the production of extraradicular hyphae and glomalin depends on the physiology and the interaction of AMF with the host plant, allowing a better understanding of the functions that AMF exert in the soil (Hart; Reader, 2002; Oehl et al., 2006; Singh et al., 2018; Marinho et al., 2019). In another study, it was also verified that the effect of AMF should be included in the interpretation of soil aggregation under a "multifunctional" perspective of the ecology of this group of fungi (Rillig; Mummey, 2006; Carneiro et al., 2015). 
Table 2: Evaluation of inoculation of AMF associated with $U$. brizantha plants. Being: root length (RL); root dry mass (RDM) and number of spores (NS), being: A. colombiana (537 UFLA); A. longula (242 UFLA); $A$. morrowiae (467 UFLA); P. occultum (438 UFLA); $G$. margarita (252 UFLA); uninoculated (NI); and absence of plant (NP). Equal letters do not differ significantly by the Tukey test at $5 \%$.

\begin{tabular}{cccc}
\hline \multirow{2}{*}{ Species } & $\mathrm{RL}$ & $\mathrm{RDM}$ & $\mathrm{NS}$ \\
\cline { 2 - 4 } & $(\mathrm{cm})$ & $\left(\mathrm{g} \mathrm{vase}^{-1}\right)$ & $\begin{array}{c}(50 \mathrm{ml} \text { of } \\
\text { soil) }\end{array}$ \\
\hline 537 (A. colombiana) & $13.68 \mathrm{a}$ & $1.75 \mathrm{a}$ & $41 \mathrm{c}$ \\
242 (A. longula) & $14.96 \mathrm{a}$ & $1.42 \mathrm{a}$ & $423 \mathrm{a}$ \\
467 (A. morrowiae) & $14.20 \mathrm{a}$ & $1.72 \mathrm{a}$ & $36 \mathrm{c}$ \\
438 (P. occultum) & $14.86 \mathrm{a}$ & $1.34 \mathrm{a}$ & $137 \mathrm{~b}$ \\
$252($ G. margarita) & $12.79 \mathrm{a}$ & $1.45 \mathrm{a}$ & $11 \mathrm{~d}$ \\
$\mathrm{NI}$ & $11.80 \mathrm{a}$ & $1.42 \mathrm{a}$ & -------- \\
$\mathrm{NP}$ & ---------- & --------- & -------- \\
CV (\%) & 14.49 & 30.21 & 14.06 \\
\hline
\end{tabular}

Means followed by the same letter in the column do not differ by the Tukey test at $5 \%$ significance.

In general, the best inoculation response for the analyzed variables was verified for species of Acaulospora, with emphasis on 537 UFLA, which presented the greatest length of extrarradicular mycelium, better influence on the stability of the dry and wet aggregates of the soil, and greater increase in the concentration of glomalin in the aggregates with $\varnothing>2.0 \mathrm{~mm}$. A better correlation of TML with the aggregation (MGDd and MGDw) of the soil was verified when compared to the GRSP (Table 3). These results indicate the greater contribution of the AMF mycelial length in the formation of soil aggregation, as demonstrated by the high positive correlation between TML and MGDd and MGDw. On the other hand, glomalin presented a positive and significant correlation with MGD for all the studied fungi and a negative correlation with MGDd. This result is due to its hydrophobic and cementing characteristics, which confer resistance of the aggregates in the presence of water.

The best aggregation of soil favors its structure by providing a greater distribution of pores in different sizes and shapes, as well as infiltration and storage of water, atmospheric air circulation, root growth, increased biological activity and various ecological relations, favoring the equilibrium of agroecosystems.

However, conservationist management and soil use are of great relevance in multiplying and/or maintaining the infective propagules of native AMF or through inoculation. Thus, AMF may aid in the formation of aggregates, structural stability and soil functional equilibrium.

Table 3: Correlation analysis of the effect of inoculation on soil aggregation: glomalin-related soil protein (GRSP), total extrarradicular mycelium length (TML), geometric mean diameter when dry (MGDd), geometric mean diameter when wet (MGDw) and aggregate stability index (ASI). The AMF include: A. colombiana (537 UFLA); $A$. longula (242 UFLA); A. morrowiae (467 UFLA); P. occultum (438 UFLA); and G. margarita (252 UFLA).

\begin{tabular}{cllllllllll}
\hline \multirow{2}{*}{ Correlation } & \multicolumn{2}{c}{ A. colombiana } & \multicolumn{2}{c}{ A. longula } & \multicolumn{2}{c}{ A. morrowiae } & \multicolumn{2}{c}{ P. occultum } & \multicolumn{2}{c}{ G. margarita } \\
\cline { 2 - 11 } & TML & GRSP & TML & GRSP & TML & GRSP & TML & GRSP & TML & GRSP \\
\hline MGDW & $0.82^{*}$ & $0.45^{\text {ns }}$ & $0.82^{*}$ & $0.88^{*}$ & $0.24^{\text {ns }}$ & $0.90^{*}$ & $0.34^{\text {ns }}$ & $0.77^{*}$ & $0.82^{*}$ & $0.95^{*}$ \\
MGDd & $0.59^{*}$ & $0.22^{\text {ns }}$ & $0.87^{*}$ & $-0.96^{*}$ & $0.68^{*}$ & $-0.82^{*}$ & $0.80^{*}$ & $-0.31^{\text {ns }}$ & $0.86^{*}$ & $-0.93^{*}$ \\
ASI & $0.63^{*}$ & $0.89^{*}$ & $0.49^{\text {ns }}$ & $-0.69^{*}$ & $0.02^{\text {ns }}$ & $0.19^{\text {ns }}$ & $0.59^{*}$ & $-0.95^{*}$ & $0.19^{\text {ns }}$ & $-0.02^{\text {ns }}$ \\
\hline
\end{tabular}




\section{CONCLUSIONS}

The studied AMF had different effects on the formation of soil aggregates, glomalin production and length of extraradicular hyphae. The inoculation with 537 UFLA (A. colombiana) showed higher geometric mean diameter of the aggregates in the dry and wet conditions. The largest length of extraradicular mycelia was verified for inoculation with 537 UFLA (A. colombiana). The highest production of glomalin was verified for inoculation with 537 UFLA (A. colombiana) in macroaggregates $(\varnothing>$ $2.0 \mathrm{~mm}$ ). Acaulospora species presented better contribution on the formation and stability of soil aggregation.

\section{ACKNOWLEDGMENT}

We thank the Coordenação de Aperfeiçoamento de Pessoal de Nível Superior (CAPES), the Conselho Nacional de Desenvolvimento Científico e Tecnologia (CNPq), and the Fundação de Amparo a Pesquisa de Minas Gerais (FAPEMIG) for the financial support and scholarships granted to the authors.

\section{REFERENCES}

BRADFORD, M. M. A rapid and sensitive method for the quantitation of microgram quantities of protein utilizing the principle of protein-dye binding. Analytical Biochemistry, 72(1):248-254, 1976.

CARNEIRO, M. A. C. et al. Arbuscular mycorrhizal fungi in soil aggregates from fields of "murundus" converted to agriculture. Pesquisa Agropecúaria Brasileira, 50(4):313-321, 2015.

DRIVER, J. D.; HOLBEN, W. E.; RILLIG, M. C. Characterization of glomalin as a hyphal wall component of arbuscular mycorrhizal fungi. Soil Biology and Biochemistry, 37(1):101-106, 2005.

FERREIRA, D. F. Sisvar. A computer statistical analysis system. Ciência e Agrotecnologia, 35(6):1039-1042, 2011.

FERREIRA, M. M.; FERNANDES, B.; CURI, N. Influência da mineralogia da fração argila nas propriedades físicas de Latossolos da região sudeste do Brasil. Revista Brasileira de Ciência do Solo, 23(3):515-524, 1999a.

FERREIRA, M. M.; FERNANDES, B.; CURI, N. Mineralogia da fração argila e estrutura de latossolos da região Sudeste do Brasil. Revista Brasileira de Ciência do Solo, 23:507-514, 1999b.

GERDEMANN, J. W.; NICOLSON, T. H. Spores of mycorrhizal endogone species extracted from soil by wet sieving and decanting. Transaction of British Mycology Society, 46(2):235-244, 1963.
GIOVANNETTI, N.; MOSSE, B. An evalution of techniques to measure vesicular-arbuscular infection in roots. New Phytologist, 84(4):489-500, 1980.

HART, M. M.; READER, R. J. Taxonomic basis for variation in the colonization strategy of arbuscular mycorrhizal fungi. New Phytologist, 153(2):335-344, 2002.

JENKINS, W. R. A rapid centrifugal-flotation technique for separating nematodes from soil. Plant Disease Report, 48(1):692, 1964.

JI, A. L.; TANA, W.; CHEN, X. Arbuscular mycorrhizal mycelial networks and glomalin-related soil protein increase soil aggregation in Calcaric Regosol under well-watered and drought stress conditions. Soil \& Tillage Research, 185:1-8, 2018.

KEMPER, W.; CHEPIL, W. Size distribution of aggregates. In: BLACK, C. A. (Ed.). Methods of Soil Analysis. Part 1. Physical and mineralogical properties, including statistics of measurement and sampling. Madison: American Society of Agronomy/Soil Society of America, p.499-510, 1965.

KINANY, S. E. et al. Effect of organic fertilizer and commercial arbuscular mycorrhizal fungi on the growth of micropropagated date palm cv. Feggouss. Journal of the Saudi Society of Agricultural Sciences, 2018. Available in: <https://www.sciencedirect.com/science/article/pii/ S1658077X17302874>. Access in: February 5, 2019.

KOHLER, J. et al. Unraveling the role of hyphal networks from arbuscular mycorrhizal fungi in aggregate stabilization of semiarid soils with different textures and carbonate contents. Plant Soil, 410:273-281, 2017.

LEHMANN, A.; ZHENG, W.; RILLIG, M. C. Soil biota contributions to soil aggregation. Nature Ecology \& Evolution, 1:18281835, 2017.

LEHMANN, E. F.; LEIFHEIT, A.; RILLIG, M. C. Mycorrhizas and soil aggregation. In: JOHNSON, N. C.; GEHRING, C.; JANSA, J. Mycorrhizal Mediation of Soil: Fertility, Structure and Carbon Storage. New York: Elsevier, p.241-262, 2017.

LIMA, J. M.; ANDERSON, S. J. Aggregation and aggregate size efects on extractable iron and aluminum in two Hapludox. Soil Science Society of America Journal, 61:965-970, 1997.

MARINHO, F. et al. High diversity of arbuscular mycorrhizal fungi in natural and anthropized sites of a Brazilian tropical dry forest (Caatinga). Fungal Ecology, 40:82-91, 2019.

MELLONI, R.; CARDOSO, E. J. B. N. Quantificação de micélio extraradicular de fungos micorrízicos arbusculares em plantas cítricas e endófitos. I. Método empregado. Revista Brasileira de Ciência do Solo, 23:53-8, 1999. 
OEHL, F. et al. Acaulospora alpina, a new arbuscular mycorrhizal fungal species characteristic for high mountainous and alpine regions of the Swiss Alps. Mycologia, 98:286-94, 2006.

PENG, S.; GUO, T.; LIU, G. The effects of arbuscular mycorrhizal hyphal networks on soil aggregations of purple soil in sothwest China. Soil Biology and Biochemistry, 57(2):411-417, 2013.

PHILLIPS, J. M.; HAYMAN, D. S. Improved procedures for clearing roots and staining parasitic and vesicular-arbuscular mycorrhizal fungi for rapid assessment of infection. Transactions of the British Mycological Society, 55:158161, 1970.

RABOT, E. et al. Soil structure as an indicator of soil functions: A review. Geoderma, 314:122-137, 2018.

RILLIG, M. C. et al. Mycelium of arbuscular mycorrhizal fungi increases soil water repellency and is sufficient to maintain water-stable soil aggregates. Soil Biology and Biochemistry, 42(7):1189-1191, 2010.

RILLIG, M. C.; MULLER, L. A.; ANIKA L. Soil aggregates as massively concurrent evolutionary incubators. The ISME Journal, 11:1943-1948, 2017.

RILLIG, M. C.; MUMMEY, D. L. Mycorrhizas and soil structure. New Phytologist, 171(1):41-53, 2006.

RUBIN, J. G. K. R.; STÜRMER, S. L. Potencial de inóculo micorrízico e importância do comprimento do micélio para a agregação de solos de ambiente fluvial. Revista Brasleira de Ciência do Solo, 39:59-68, 2015.

SILVIA, I. F.; MIELNICZUK, J. Ação do sistema radicular de plantas na formação e estabilização de agregação do solo. Revista Brasileira de Ciência do Solo, 20:113-117, 1997.
SINGH, P G. et al. Crop rotation and residue management effects on soil enzyme activities, glomalin and aggregate stability under zero tillage in the Indo-Gangetic. Soil \& Tillage Research, 184:291-300, 2018.

SOIL SURVEY STAFF. Soil taxonomy: A basic system of soil classification for making and interpreting soil surveys. Natural Resources Conservation Service. Department of Agriculture, United States, 2014, p.372.

STEINBERG, P. D.; RILLIG, M. C. Differential decomposition of arbuscular mycorrhizal fungal hyphae and glomalin. Soil Biology and Biochemistry, 35(1):191-194, 2003.

TISDALL, J. M.; OADES, J. M. Organic matter and water-stable aggregates in soils. European Journal of Soil Science, 33(2):141-163, 1982.

VILELA, L. A. et al. Arbuscular mycorrhizal fungi in microbial activity and aggregation of a cerrado oxisol in crop sequence. Ciência e Agrotecnologia, 38(1):34-42, 2014.

WRIGHT, S.; UPADHYAYA, A. A survey of soils for aggregate stability and glomalin, a glycoprotein produced by hyphae of arbuscular mycorrhizal fungi. Plant and Soil, 198(1):97-107, 1998.

WRIGHT, S. F.; NICHOLS, K. A. Glomalin: Hiding place for a third of the world's stored soil carbon. Agricultural Research, 50, 4-7, 2002.

YE, L. et al. Spatial analysis of soil aggregate stability in a small catchment of the Loess Plateau, China: I. Spatial variability. Soil \& Tillage Research, 179:7-81, 2018.

YODER, R. E. A direct method of agregate analysis of soil and a study of the physical nature of erosion losses. Journal of America Society of Agronomy, 28:337-351, 1936. 